ROCZNIKI TEOLOGICZNE

Tom LXVIII, zeszyt $11-2021$

DOI: https://doi.org/10.18290/rt216811-3

\author{
REV. CARL-MARIO SULTANA
}

\title{
A PASTORAL READING OF THE DIRECTORY FOR CATECHESIS
}

\begin{abstract}
A b stract. The recently published Directory for Catechesis by the Pontifical Council for Promoting the New Evangelisation is the handbook for all those who are involved in the catechetical ministry, ranging from Bishops and Bishops' Conferences to pastors, priests and lay catechists. This article seeks to take a pastoral glance at the Directory which offers a vision for catechesis which is founded on the theology of Evangelii Gaudium, with an openness to a more kerygmatic catechesis. Moreover, the Directory seeks to situate catechesis within the contemporary digital culture, whilst not neglecting traditional stances such as the Catechumenate and mystagogy. The Directory also taps into innovative methodological aids such as the value given to the way of beauty.
\end{abstract}

Keywords: Directory for Catechesis; kerygmatic catechesis; digital culture; Catechumenate and mystagogy; the way of beauty.

The long-awaited new Directory for Catechesis (=Directory) has been approved and promulgated on the $23^{\text {rd }}$ March $2020^{1}$ by Pope Francis after 5 years of intensive work by the Pontifical Council for Promoting the New Evangelisation. This Pontifical Council was entrusted with an update to the Directory in order to reflect the current contemporary socio-cultural and religious context. The fact that several experts from the field and from diverse countries and situations were consulted ${ }^{2}$ in order to make this docu-

Rev. Dr CARL-Mario Sultana - He is a Head of Department of Pastoral Theology, Liturgy and Canon Law in the Faculty of Theology, University of Malta. He also forms part of the Secretariat for Catechesis where he is the Archbishop's Delegate for Catechesis. He is a member of the Committee of the Equipe Europeenne de Catechese (EEC) end the Secretary for the Catechesis Section of the Commission for Evangelisation and Culture within the CCEE (Consilium Conferentiarium Episcoporum Europae) - the Council of the Episcopal Conferences of Europe. He is a member of the Equipe Europeenne de Catechese (EEC), the Association for Children Spirituality and the European Society for Catholic Theologians (ESCT); e-mail: carl.m.sultana@um.edu.mt.

${ }^{1}$ Cf. Pontifical Council for Promoting New Evangelization, Directory for Catechesis $\left(23^{\text {rd }}\right.$ March 2020) (London: The Incorporated Catholic Truth Society, 2020).

${ }^{2}$ Cf. Directory, p. 20. 
ment a true guide which reflects the needs of the contemporary sociocultural and catechetical contexts augurs well for both the reception and the overall outlook of the Directory.

\section{THE DIRECTORY AS A TOOL}

The Directory for Catechesis as the term 'directory' implies seeks to give a direction, it directs the reader to a particular goal. Its aim is to help all those who in some way are engaged in the catechetical ministry, commencing from Bishops down to catechists, and the general reader to have a vision towards which one seeks to move, and which one strives to achieve. The Directory states this from the very beginning:

The new Directory for Catechesis offers fundamental theological-pastoral principles and some general guidelines that are relevant for the practice of catechesis in our time. It is natural that their application and the operative guidelines should be a task for the particular Churches, called to provide an elaboration of these common principles, so that they may be inculturated in their own ecclesial context. This Directory, therefore is a tool for the elaboration of the national or local directory...capable of translating the general guidelines into the language of the respective ecclesial communities. ${ }^{3}$

Its aim is not to limit the extent of catechesis in terms of what is being proposed in the Directory. It does not seek uniformity at all costs, but it is aimed at kindling creativity in catechesis which is in line with the general principles presented in the Directory, and which are also in tune with the particular socio-cultural, pastoral and catechetical milieu in which they are put into practice in the different dioceses and parochial realities around the world.

To help the reader to focus more on the themes within the Directory, this has been divided into three distinct parts, which among them constitute the twelve chapters of the Directory. These three parts are enclosed in an Introduction, ${ }^{4}$ and a Conclusion. ${ }^{5}$ Part One of the Directory, entitled Catechesis in the Church's Mission of Evangelization seeks to set the foundation on which the entire document is based. This part is divided into four chapters respec-

\footnotetext{
${ }^{3}$ Directory, no. 10.

${ }^{4}$ Cf. Directory, no. 1-10.

${ }^{5}$ Cf. Directory, no. 426-428.
} 
tively entitled: Revelation and its Transmission; ${ }^{6}$ The Identity of Catechesis $;{ }^{7}$ The Catechist ${ }^{8}$ and The Formation of Catechists. ${ }^{9}$

The Second Part of the Directory - The Process of Catechesis - deals more specifically with catechesis as a process of formation for the faith. It also contains four chapters respectively entitled: The Pedagogy of the Faith; ${ }^{10}$ The Catechism of the Catholic Church $;{ }^{11}$ Methodology in Catechesis $;{ }^{12}$ and Catechesis in the Lives of Persons. ${ }^{13}$

The Third and final part of the Directory is more addressed to catechesis in particular situations - Catechesis in the Particular Churches. This part is divided into four chapters respectively entitled: The Christian Community as Participant in Catechesis $;{ }^{14}$ Catechesis in the Face of Contemporary Cultural Scenarios ${ }^{15}$ Catechesis at the Service of the Inculturation of the Faith $;{ }^{16}$ and The Organisms at the Service of Catechesis. ${ }^{17}$

This paper seeks to give a pastoral reading of the new Directory for Catechesis in terms of keywords. It will elaborate on those themes which in the Directory are intriguing and to some extent also original. One of the limitations of this study is that it does not seek to expound on all the original themes found in the Directory. Moreover, one must also keep in mind that these themes are being read from the European point of view. Still, they are applicable universally.

The themes which will be developed throughout the rest of this paper are:

1. Evangelii Gaudium as the firm foundation of the new Directory

2. Kerygmatic Catechesis

3. The Catechumenate

${ }^{6}$ Cf. Directory, no. 11-54.

${ }^{7}$ Cf. Directory, no. 55-109.

${ }^{8}$ Cf. Directory, no. 110-129.

${ }^{9}$ Cf. Directory, no. 130-156.

${ }^{10}$ Cf. Directory, no. 157-181.

${ }^{11}$ Cf. Directory, no. 182-193.

${ }^{12}$ Cf. Directory, no. 194-223.

${ }^{13}$ Cf. Directory, no. 224-282.

${ }^{14}$ Cf. Directory, no. 283-318.

${ }^{15}$ Cf. Directory, no. 319-393.

${ }^{16}$ Cf. Directory, no. 394-408.

${ }^{17}$ Cf. Directory, no. 409-425. More about the genesis and structure of catechetical directories, cf. Andrzej Kiciński, "Rozwój dyrektoriów katechetycznych po Soborze Watykańskim II (1971-1997-2020) [Development of Catechetical Directories after the Second Vatican Council (1971-1997-2020)]," Roczniki Teologiczne 67(2020), 11: 5-27. 
4. The human being in the contemporary social and cultural context - the digital culture

5. Mystagogy

6. The way of Beauty - Via Pulchritudinis

\section{EVANGELII GAUDIUM AS THE FIRM FOUNDATION}

As with the other previous two Directories for Catechesis, the new Directory is based on the theology which is being developed in our contemporary society as a result of the Church's reading of the signs of the times. One must keep in mind that the General Catechetical Directory $(1971)^{18}$ was a result of what had just happened in the previous years, namely Vatican Council II. ${ }^{19}$ The outlook and vision of the 1997 General Directory for Catechesis ${ }^{20}$ was the result of Magisterial Documents which had preceded it, namely, but not limited to Evangelii Nuntiandi (1975), ${ }^{21}$ Catechesi Tradendae (1979), ${ }^{22}$ the Catechism of the Catholic Church (1992), ${ }^{23}$ and Fidei Depositum (1992). ${ }^{24}$

It is clear that Evangelii Gaudium ${ }^{25}(=\mathrm{EG})$ is the foundation on which the Directory is solidly positioned. The amount of direct and indirect references

${ }^{18}$ Cf. Sacred Congregation for the Clergy, General Catechetical Directory, 11.04.1971 [online] [access: 22.10.2020]. Available online at: <http://www.vatican.va/roman_curia/congregations/cclergy /documents/rc_con_cclergy_doc_11041971_gcat_en.html>.

${ }^{19}$ Cf. Vatican Council II, 1962-1965 [online] [access: 22.10.2020]. Available online at: <http:// www.vatican.va/archive/hist_councils/ii_vatican_council/index.htm>.

${ }^{20} \mathrm{Cf}$. Congregation for the Clergy, General Directory for Catechesis, 11.08.1997 [online] [access: 22.10.2020]. Available online at: $<$ http://www.vatican.va/roman_curia/congregations/cclergy /documents/rc_con_ccatheduc_doc_17041998_directory-for-catechesis_en.html>.

${ }^{21}$ Cf. Paul VI, Apostolic Exhortation Evangelii Nuntiandi, 8.12.1975 [online] [access: 22.10.2020]. Available online at: <http://www.vatican.va/content/paul-vi/en/apost_exhortations/ documents/hf_p-vi_exh_19751208_evangelii-nuntiandi.html $>$.

${ }^{22}$ Cf. John Paul II, Apostolic Exhortation Catechesi Tradendae, 16.10.1979 [online] [access: 20.10.2020]. Available online at: <http://www.vatican.va/content/john-paul-ii/en/apost_exhortations /documents/hf_jp-ii_exh_16101979_catechesi-tradendae.html $>$.

${ }^{23}$ Cf. John Paul II, Catechism of the Catholic Church, 1992 [online] [access: 20.10.2020]. Available online at: $<$ http://www.vatican.va/archive/ccc/index.htm>.

${ }^{24}$ Cf. John Paul II, Apostolic Constitution Fidei Depositum, 11.10.1992 [online] [access: 20.10.2020]. Available online at: <http://w2.vatican.va/content/john-paul-ii/en/apost_constitutions/ documents/hf_jp-ii_apc_19921011_fidei-depositum.html>.

${ }^{25}$ Cf. Francis, Apostolic Exhortation Evangelii Gaudium, 24.11.2013 [online] [access: 20.10.2020]. Available online at: <http://www.vatican.va/content/francesco/en/apost_exhortations/ documents/papa-francesco_esortazione-ap_20131124_evangelii-gaudium.html>. 
to EG attest to this. Whilst the 1997 General Directory for Catechesis has a myriad of footnotes which were aimed at helping those who were studying it to further deepen the ideas and concepts within it, the new Directory has much less references. However, when one takes a closer look at these references, one finds that there are quite a substantial amount of them which refer to EG. It can indeed be noted that EG is always referred to in order to give more value and strength to the point being made. Therefore, EG reinforces the particular position which is being made.

Having EG as a point of departure and as the same time as a vision towards which one is seeking to move, implies that there are certain aspects which are highlighted more than others. Amongst these, we find the strict link which there is between evangelisation and catechesis. Indeed, catechesis is rightly seen within the context of evangelisation, and as an integral part of it. ${ }^{26}$ The Directory insists that catechesis has to be seen as "a privileged stage in the process of evangelisation." 27 The divisions within the process of evangelisation and of catechesis respectively are re-worded. Nonetheless, they essentially remain the same but reflect the new exigencies of our times with regards to evangelisation and catechesis. ${ }^{28}$

EG 169-173 propose personal accompaniment as one of the methods which has to be used in presenting the Gospel to our interlocutors in our contemporary society. The new Directory similarly considers personal accompaniment as a very important aspect in contemporary catechesis. This is especially so in the formation of catechists, who truly need to be formed as companions on the journey during the process of catechesis. ${ }^{29}$ Personal accompaniment is also an important and integral part of the process of catechesis with specific categories of persons, for example, when accompanying families $^{30}$ and when accompanying adults. ${ }^{31}$

In various parts of EG, Pope Francis calls the Church to embrace a missionary outlook and a missionary transformation. The new Directory picks up this new way of looking at the mission of evangelisation and of catechesis in our contemporary world and proposes "the need for a renewed impulse of evangelisation [which] justifies the decision to rethink in a missionary vein all the pastoral activities of the Christian community, even the most

\footnotetext{
${ }^{26}$ Cf. Directory, no. 66-74.

${ }^{27}$ Directory, no. 56.

${ }^{28}$ Cf. Directory, no. 31-41; 66-74.

${ }^{29}$ Cf. Directory, no. 113, 135.

${ }^{30}$ Cf. Directory, no. 235.

${ }^{31}$ Cf. Directory, no. 263-265.
} 
ordinary and traditional ones. Catechesis as well is touched by demands of missionary conversion to which the parish is called." 32 Within the specific realm of the parish, the Directory speaks of a missionary transformation in terms of three particular aspects:

a. forming a community of missionary disciples not of experts who know it all;

b. forming a missionary mentality, that is, a tension to listen to others and to go out to listen to the experiences of people and illuminate these with the Gospel;

c. present formative experiences (inspired by the catechumenate) which make it possible to get to know, and to accept the kerygma. ${ }^{33}$

It is interesting to note that the Directory elaborates only on five tasks of catechesis. ${ }^{34}$ The task which regards missionary initiation as this was present in the General Directory for Catechesis ${ }^{35}$ is totally omitted in the new Directory. The reason for this may be found in the fact that the missionary dimension of catechesis is a transversal theme in the new Directory, and it crosses through several other themes which are elaborated upon in the Directory.

\section{KERYGMATIC CATECHESIS}

The new Directory emphatically proposes a kerygmatic type of catechesis without seeking to take us back in time to the kerygmatic movement which was typical of catechesis in the 1930's through to the 1960 's. ${ }^{36}$ The inspiration to move towards a more kerygmatic type of catechesis comes from EG:

In catechesis too, we have rediscovered the fundamental role of the first announcement or kerygma, which needs to be the centre of all evangelizing activity and all efforts at Church renewal... This first proclamation is called "first" not because it exists at the beginning and can then be forgotten or replaced by other more important things. It is first in a qualitative sense because it is the principal proclamation, the one which we must hear again and again in different ways, the

\footnotetext{
${ }^{32}$ Directory, no. 303.

${ }^{33}$ Cf. Directory, no. 303.

${ }^{34}$ Cf. Directory, no. 79-89.

${ }^{35}$ Cf. General Directory for Catechesis, 86.

${ }^{36} \mathrm{Cf}$. Giuseppe Biancardi, Ubaldo Gianetto, Storia della catechesi. 4. Il movimento catechistico (Roma: LAS, 2016), 201-215; Carl-Mario Sultana, "Catechesis in Europe during the 20th Century," in: Sophia-Paideia. Sapienza e Educazione (Sir 1, 27). Miscellanea di studi offerti in onore del Prof. Don Mario Cimosa, ed. by Gillian Bonney and Rafael Vicent (Roma: LAS, 2012), 426-430.
} 
one which we must announce one way or another throughout the process of catechesis, at every level and moment...We must not think that in catechesis the kerygma gives way to a supposedly more "solid" formation. Nothing is more solid, profound, secure, meaningful and wisdom-filled than that initial proclamation. All Christian formation consists of entering more deeply into the kerygma, which is reflected in and constantly illumines, the work of catechesis, thereby enabling us to understand more fully the significance of every subject which the latter treats. It is the message capable of responding to the desire for the infinite which abides in every human heart. ${ }^{37}$

This text from EG is frequently referred to and at times also reproduced in different parts of the new Directory. ${ }^{38}$ Moreover, the Directory insists that a kerygmatic presentation of the Good News is not only important during the first proclamation, but it should be the distinguishing characteristic of all the different phases and forms of catechesis with all the different categories and ages of interlocutors. ${ }^{39}$

A very pertinent question is: What is meant by kerygmatic catechesis in the new Directory? This question needs to be answered in an adequate way if we are seeking to understand the new vision which is being proposed by the Directory. When we are speaking of a kerygmatic catechesis, we are also saying that the primary aim of all our catechetical endeavours should be the proclamation of the Good News. If we want kerygmatic catechesis as a term not to end up a cliché - as what happened with the term 'new evangelisation' - we have to see that this is rooted not only in the message of the Gospel, but that it also deeply seated in the proclamation of a Person - Jesus Christ. ${ }^{40}$

Consequently, a kerygmatic catechesis seeks to do away with the simple transmission of information about Jesus in an abstract way. It tries to touch the practical reality in which the contemporary human being is living, and with which s/he is striving. A kerygmatic catechesis presents Jesus as a person who is not only interested in our qualms and anxieties, but as God with us, accompanying us throughout our lives. It is only in this way that we can present Jesus as the Good News for each and every generation in a fresh way. It is only in presenting Jesus as the Good News that the human being discovers himself as the image of God, called to be in union with him - the

\footnotetext{
${ }^{37}$ Evangelii Gaudium, 164-165.

${ }^{38}$ Cf. Directory, no. 68.

${ }^{39}$ Cf. Directory, no. 57.

${ }^{40}$ Cf. Directory, no. 57-60; 75-78.
} 
reason for which human beings were created. ${ }^{41}$ As a result, the faith presented through a kerygmatic type of catechesis is not something which is distant from the person, or which pertains to the past, but it is an event which touches human beings within the same reality which they are living. It therefore presents itself as an ever-present and relevant reality.

One of the characteristics of presenting Jesus Christ as the Good News of salvation is mercy. A kerygmatic type of catechesis cannot do away with the proclamation of God's mercy. The concept of mercy is typical of Pope Francis' Christology which overflows abundantly into his anthropology. A kerygmatic catechesis constitutes presenting Jesus as close to the human being not to condemn him/her but to offer mercy and reconciliation. It is only through the gift of mercy that human beings discover themselves as individuals who have not been abandoned by God to their fate but as persons invited to enter into communion with him. ${ }^{42}$ Mercy can be more evidently and emphatically presented as such during the process of catechesis with specific categories of people, such as in prisons. ${ }^{43}$ Mercy is also one of the characteristics of a kerygmatic catechesis during the catechumenate where the catechumen experiences God's mercy in the remission of sins on receiving the Sacraments of Initiation. ${ }^{44}$

\section{THE CATECHUMENATE}

The Catechumenate as a process of Christian initiation is proposed "as a source of inspiration for catechesis." 45 It is projected as the model on which all the different forms of catechesis with different categories of people is planned and put into action. ${ }^{46}$ It is also presented as the model par excellence of an experience of mercy and of reconciliation, both with fellow human beings and with God.

The Directory strongly proposes a pastoral conversion where the catechumenate as a process for Christian Initiation is concerned. This is a result of the fact that the Catechumenate throughout the years has presented the Church in general, and parishes in particular with several aspects which need

\footnotetext{
${ }^{41}$ Cf. Directory, no. 2, 33b, 57-60, 175, 196, 303b.

${ }^{42}$ Cf. Directory, no. 303b, 327.

${ }^{43}$ Cf. Directory, no. 282.

${ }^{44}$ Cf. Directory, no. 65.

${ }^{45}$ Directory, no. 61.

${ }^{46}$ Cf. Directory, no. 2, 242.
} 
to be urgently revised ${ }^{47}$ Amongst those where a pastoral conversion is called for, we find:

1. that catechesis during the period of the catechumenate should distance itself as much as possible from dishing out information and instruction which is typical of a school setting. It should not give information about Jesus and the Catholic faith by a catechist who knows a lot of information about Jesus, but it needs to take the form of a practical experience, and of an apprenticeship in the faith and in getting to know Jesus through a personal experience, ${ }^{48}$

2. all catechesis imparted in the catechumenate should distance itself from any form of imposition, even when we are speaking of truths which cannot be negated. Contrary to any form of imposition, catechesis during the catechumenate should propose the faith in the form of a dialogue with the individual who is called to make a free personal decision to assent to the faith ${ }^{49}$

3. the catechumenate needs to reconsider the importance of a progressive catechesis, as directly opposed to giving everything at once. The gradual entry into the mystery of Christ and of the Church need to be safeguarded, whilst gradually inserting the individual in a continuous process of getting to know Jesus more. ${ }^{50}$ The hierarchy of truths can help in safeguarding this $;^{51}$

4. catechesis during the catechumenate is not to be presented as the token for the Sacraments of Initiation in such a way that once the Sacraments have been received then there is a void due to a lack of mystagogy and of permanent and ongoing formation; ${ }^{52}$

5. the Sacraments of Initiation should not be used as a pastoral excuse for administering the Sacrament of Confirmation at an earlier age, with the reasoning that if this is delayed, we will lose numbers. Such reasoning empties the Sacrament of its importance and of the mystery within it. Moreover, one should not conduct experiments with the Sacraments of Initiation. ${ }^{53}$

\footnotetext{
${ }^{47}$ Cf. Directory, no. 300-303.

${ }^{48}$ Cf. Directory, no. 297.

${ }^{49}$ Cf. Directory, no. 53, 142,260,396.

${ }^{50} \mathrm{Cf}$. Directory, no. 61, 63, 64f.

${ }^{51}$ Cf. Directory, no. 178-179.

${ }^{52}$ Cf. Directory, no. $97-98$

${ }^{53} \mathrm{Cf}$. Directory, no. 70.
} 


\section{THE HUMAN BEING \\ AND THE CONTEMPORARY SOCIO-CULTURAL CONTEXT - THE DIGITAL CULTURE}

The Directory acknowledges that we can never speak with the human being as if we are in a vacuum, that is, without considering the socio-cultural context in which human beings are living today. In this respect, besides the normal aspects of inculturation, ${ }^{54}$ complex situations of pluralism, ${ }^{55}$ popular piety, ${ }^{56}$ ecumenism, ${ }^{57}$ academic and scientific communities, ${ }^{58}$ bioethics, ${ }^{59}$ engagement with the environment, ${ }^{60}$ the world of work, ${ }^{61}$ and poverty, ${ }^{62}$ amongst others, the Directory specifically speaks of the digital culture in which the contemporary human being is immersed today. ${ }^{63}$

The point of departure when considering the human being in the digital culture is the presence of the Church in the digital arena. The presence of the Church through various digital media is a step in the right direction. However, we cannot be satisfied simply by such a move. For a better and fruitful ministry within the digital culture, we need to understand some of the characteristics of the contemporary digital culture. These are an enhancement to the normal modus operandi, and amongst these positive traits we find that:

1. it is truly a new culture which endorses a different language, a new mentality, and even new hierarchy of values;

2. it is an opportunity for encounter and for dialogue which is not hindered by spatial barriers;

3. it offers a much broader access to information and knowledge;

4. it promotes the social involvement of the human being, especially through the social media;

5. it also acts as an aide-mémoire. ${ }^{64}$

Notwithstanding these positive aspects, there is also a dark side to the digital culture:

\footnotetext{
${ }^{54}$ Cf. Directory, no. 394-406.

${ }^{55}$ Cf. Directory, no. 319-335.

${ }^{56}$ Cf. Directory, no. 336-342.

${ }^{57}$ Cf. Directory, no. 343-353.

${ }^{58}$ Cf. Directory, no. 354-358.

${ }^{59}$ Cf. Directory, no. 373-378.

${ }^{60}$ Cf. Directory, no. 381-384.

${ }^{61}$ Cf. Directory, no. 392-393.

${ }^{62}$ Cf. Directory, no. 385-388.

${ }^{63}$ Cf. Directory, no. 359-372.

${ }^{64}$ Cf. Directory, no. 359-360.
} 
1. it can cultivate a culture of loneliness and isolation, hindering the development of authentic relationships;

2. it can allow for the possibility of manipulation by creating a distorted vision of reality;

3 . there is a risk of addiction, sexual exploitation and violence;

4. it can act as a vehicle for the spread of fake news and false information. ${ }^{65}$

The contemporary human being is so immersed in the digital culture that it is impossible to understand the human being fully if one disregards the digital age in which all humanity is living. The digital culture has indeed become an integral part of human anthropology: human beings understand and react to the world around them using criteria from the digital culture. This is the reason why understanding the digital culture is so important for a fecund catechetical ministry. We also need to be aware that the digital culture has an impact on how the human being looks at the truth, even immutable truths. These are at times considered on par with virtual reality, thus emptying them of their true significance, meaning and grandeur. ${ }^{66}$ Moreover, what is virtual in the digital world is considered as real and on the same level as the Truths of a Sacred and Religious Nature. This is a situation which may lead to syncretism and apotheosis, where everything is put on the same level, to the detriment of revealed Truths. ${ }^{67}$

What should be the characteristics of catechesis in this digital era?

- Primarily, it must start by understanding the power of the medium and use its positive aspects to the full. Still, we should not stop short in knowing how to use the digital media, but we should seek "to become an evangelising presence on the digital continent; $" 68$

- it must seek to present pathways to the faith that exploit the unique identity of the individual;

- still, the process, while being personalised needs to insert the interlocutor into the community of believers, and not leave him/her isolated;

- it should clarify religious language which at times has been adopted for online purposes;

\footnotetext{
${ }^{65}$ Cf. Directory, no. 361

${ }^{66}$ Cf. Directory, no. 362-362.

${ }^{67}$ Cf. Directory, no. 365-369.

${ }^{68}$ Directory, no. 371.
} 
- it should find adequate means to answer the existential questions of human beings. ${ }^{69}$

One of the important considerations of the digital culture is that the $D i$ rectory makes us aware that nothing is static as in the past, but everything is constantly changing, even the human being. So, we need to be on the alert for changes so that we react and adjust accordingly and in due time.

\section{MYSTAGOGY}

The Directory presents mystagogy as a special moment in the catechumenate, but which should not be strictly limited to it. ${ }^{70}$ Consequently, Mystagogy should not be considered as an optional aspect of the catechumenate. It is indeed necessary because it gives meaning to our catechetical endeavours in terms of:

1. an interpretation of the rites and of the sacraments in the light of the events of salvation;

2. explaining the meaning of liturgical signs and symbols;

3. presenting a holistic approach to the Sacraments of Initiation, giving them meaning in terms of living a truly Christian life. ${ }^{71}$

However, without watering down the meaning of mystagogy as an integral part of the catechumenate, or of emptying it of its distinctive features, the concept of mystagogy is widened in the new Directory. As a result, it is extended beyond the limits of the catechumenate in virtue of the way in which it seeks to help and to accompany individuals in continuing to accept Christ in their life and who on their part seek to keep on inserting themselves in the mystery of Christ, and to allow Christ to enlighten their lives, words and choices. This makes mystagogy a process which runs through a whole lifetime.

\section{THE WAY OF BEAUTY}

One of the novelties of the Directory is that it considers the way of Beauty - the via pulchritudinis - as one of the sources of catechesis. ${ }^{72}$ This has

\footnotetext{
${ }^{69}$ Cf. Directory, no. 370-372.

${ }^{70}$ Cf. Directory, no. 35, 63-64.

${ }^{71}$ Cf. Directory, no. 98.

${ }^{72}$ Cf. Directory, no. 106-109.
} 
been indeed so for many centuries, where art played a very important educational aspect in times when people were not as literate as they are today. Here expressions such as biblia pauperum come to mind. In the past, this enabled the presentation of the mysteries of salvation through visual art in churches to uneducated and illiterate people.

Notwithstanding the fact that as a human race we have made strides ahead in education and in instilling a culture of learned human beings, the way of beauty remains one of the sources of catechesis which can reach human beings today in the real context in which they are living. By considering the way of beauty as one of the sources of catechesis, we are referring to art, literature, music and other forms of beauty. ${ }^{73}$ Such works of beauty exist in each and every particular Church and they are able to point at God and to somewhat demonstrate the beauty of God. Moreover, they induce human beings to ask questions of an existential nature which would ultimately lead to God. All local Churches are very rich and offer a great opportunity in this respect.

\section{CONCLUSION}

One must admit that we had to wait for quite some time to have the final official version of the new Directory, but today, in hindsight, one must say that it was worth the wait. This article has just scraped the surface of this document with the vision it presents. Notwithstanding this, one must admit that the Directory truly gives a new and comprehensive vision for catechesis for our contemporary time. The new Directory truly justifies its position and outlook for catechesis in the light of the contemporary human being and socio-cultural milieu in which we are living. It is now the task of those responsible for catechesis to see that this is put into practice in the best way possible.

\section{BIBLIOGRAPHY}

Biancardi, Giuseppe, Ubaldo Gianetto. Storia della catechesi. 4. Il movimento catechistico. Roma: LAS, 2016.

Congregation for the Clergy. General Directory for Catechesis, 11.08.1997 [online] [access: 22.10.2020]. Available online at: <http://www.vatican.va/roman_curia/congregations/cclergy/ documents/rc_con_ccatheduc_doc_17041998_directory-for-catechesis_en.html>.

\footnotetext{
${ }^{73}$ Cf. Directory, no. 209-212.
} 
Francis. Apostolic Exhortation Evangelii Gaudium, 24.11.2013 [online] [access: 20.10.2020]. Available online at: <http://www.vatican.va/content/francesco/en/apost_exhortations/ documents / papa-francesco_esortazione-ap_20131124_evangelii-gaudium.html $>$.

John Paul II. Apostolic Constitution Fidei Depositum, 11.10.1992 [online] [access: 20.10.2020]. Available online at: $<\mathrm{http} / /$ w2.vatican.va/content/john-paul-ii/en/apost_constitutions/documents/ hf_jp-ii_apc_19921011_fidei-depositum.html $>$.

John Paul II. Apostolic Exhortation Catechesi Tradendae, 16.10 .1979 [online] [access: 20.10.2020]. Available online at: $<$ http://www.vatican.va/content/john-paul-ii/en/apost_exhortations/documents/ hf_jp-ii_exh_16101979_catechesi-tradendae.html>.

John Paul II. Catechism of the Catholic Church, 1992 [online] [access: 20.10.2020]. Available online at: <http://www.vatican.va/archive/ccc/index.htm>.

Kiciński, Andrzej. "Rozwój dyrektoriów katechetycznych po Soborze Watykańskim II (1971-1997-2020)." Roczniki Teologiczne 67(2020), 11: 5-27.

Paul VI. Apostolic Exhortation Evangelii Nuntiandi, 8.12.1975 [online] [access: 20.10.2020]. Available online at: <http://www.vatican.va/content/paul-vi/en/apost_exhortations/documents/ hf_p-vi_exh_19751208_evangelii-nuntiandi.html>.

Pontifical Council for Promoting New Evangelization. Directory for Catechesis, 23.03.2020. London: The Incorporated Catholic Truth Society, 2020.

Sacred Congregation for the Clergy. General Catechetical Directory, 11.04.1971 [online] [access: 20.10.2020]. Available online at: $<\mathrm{http} / /$ www.vatican.va/roman curia/congregations/cclergy/ documents/rc_con_cclergy_doc_11041971_gcat_en.html>.

Sultana, Carl-Mario. "Catechesis in Europe during the 20th Century." In Gillian Bonney, Rafael Vicent (eds.). Sophia-Paideia. Sapienza e Educazione (Sir 1,27). Miscellanea di studi offerti in onore del Prof. Don Mario Cimosa, 423-450. Roma: LAS, 2012.

Vatican Council II, 1962-1965 [online] [access: 20.10.2020]. Available online at: <http://www. vatican.va/archive/hist_councils/ii_vatican_council/index.htm>.

\section{ANALIZA PASTORALNA DYREKTORIUM O KATECHIZACJI}

\section{Streszczenie}

Ostatnio opublikowane przez Papieską Radę ds. Krzewienia Nowej Ewangelizacji Dyrektorium o katechizacji jest podręcznikiem dla wszystkich, którzy są zaangażowani w posługę katechetyczną, począwszy od biskupów i konferencji biskupich, poprzez proboszczów, kapłanów, aż po katechetów świeckich. Niniejszy artykuł jest próbą pastoralnego spojrzenia na Dyrektorium, które proponuje wizję katechezy opartą na teologii Evangelii Gaudium, z otwartością na katechezę bardziej kerygmatyczną. Ponadto Dyrektorium stara się umiejscowić katechezę w obrębie współczesnej kultury cyfrowej, nie zaniedbując przy tym tradycyjnych podstaw, takich jak katechumenat i mistagogia. Dyrektorium sięga także po nowatorskie pomoce metodologiczne, takie jak dowartościowanie drogi piękna.

Słowa kluczowe: Dyrektorium o katechizacji; katecheza kerygmatyczna; kultura cyfrowa; katechumenat i mistagogia; droga piękna. 